\title{
Dissemination of clonal complex 2 Acinetobacter baumannii strains co-producing carbapenemases and 16S rRNA methylase ArmA in Vietnam
}

\author{
Tatsuya Tada' ${ }^{1}$ Tohru Miyoshi-Akiyama², Kayo Shimada', Tran Thi Thanh $\mathrm{Nga}^{3}$, Le Thi Anh Thu ${ }^{3}$,
} Nguyen Truong Son ${ }^{3}$, Norio Ohmagari ${ }^{4}$ and Teruo Kirikae ${ }^{1 *}$

\begin{abstract}
Background: Acinetobacter baumannii strains co-producing carbapenemase and 16S rRNA methylase are highly resistant to carbapenems and aminoglycosides.

Methods: Ninety-three isolates of multidrug-resistant A. baumannii were obtained from an intensive care unit in a hospital in Vietnam. Antimicrobial susceptibility tests and whole genome sequencing were performed. Multilocus sequence typing and the presence of drug resistant genes were determined and a maximum-likelihood phylogenetic tree was constructed by SNP alignment of whole genome sequencing data.
\end{abstract}

Results: The majority of isolates belonged to clonal complex 2 (ST2, ST570 and ST571), and carried carbapenemase encoding genes b/a $a_{\mathrm{OXA}-23}$ and bla $a_{\mathrm{OXA}-66}$. Two isolates encoded carbapenemase genes b/a $a_{\mathrm{NDM}-1}$ and bla $a_{\mathrm{OXA}-58}$ and the $16 \mathrm{~S}$ rRNA methylase encoding gene armA and did not belong to clonal complex 2 (ST16).

Conclusion: A. baumannii isolates producing 16S rRNA methylase ArmA and belonging to clonal complex 2 are widespread, and isolates co-producing NDM-1 and ArmA are emerging, in medical settings in Vietnam.

Keywords: Multidrug-resistance, Acinetobacter baumannii, $16 \mathrm{~S}$ rRNA methylase ArmA, Metallo- $\beta$-lactamase NDM-1, Intensive care unit

\section{Background}

Metallo- $\beta$-lactamases (MBLs) confer reduced susceptibility to carbapenems, cephalosporins, and all penicillins except monobactams [1]. Acquired MBLs are produced by several Gram-negative bacterial strains, including Acinetobacter spp., Pseudomonas aeruginosa, and several Enterobacteriaceae [1]. MBLs are categorized by their amino acid sequences into various types [2-4], including AIM [5], DIM [6], FIM [7], GIM [8], IMPs [9], KHM [10], NDMs [11], SMB [12], SIM [13], SPM [14], TMBs [15] and VIMs [16]. The most prevalent MBLs are IMP-, VIM-, and NDM-type enzymes $[1,2,17]$. NDM-1 was initially isolated from Klebsiella pneumoniae and Escherichia coli in 2008 in Sweden

\footnotetext{
* Correspondence: tkirikae@rincgm.go.jp

'Department of Infectious Diseases, Research Institute, National Center for Global Health and Medicine, Shinjuku, Tokyo, Japan

Full list of author information is available at the end of the article
}

[11]. Between 2009 and 2012, 950 isolates of NDM-1producing bacteria, including $36 \mathrm{~A}$. baumannii isolates, were reported worldwide [18]. Subsequently, at least 13 NDM variants (www.lahey.org/studies) have been reported in several countries [4, 19-30].

Aminoglycosides are effective antibiotics for the treatment of infectious diseases caused by Gram-negative bacteria. These agents block bacterial protein synthesis by binding to the $30 \mathrm{~S}$ ribosomal subunit [31]. Methylation of $16 \mathrm{~S}$ rRNA by $16 \mathrm{~S}$ rRNA methylases, however, makes Gram-negative bacteria highly resistant to all clinically important aminoglycosides [32]. In 2003, clinical isolates of highly aminoglycoside-resistant Gram-negative bacteria producing 16S rRNA methylases were identified in France [33] and Japan [34]. Since then, 16S rRNA methylaseproducing Gram-negative bacteria have been isolated in other parts of the world, including Asian countries, such 
as Afghanistan, Bangladesh, China, Hong Kong, India, Japan, Korea, Oman, and Pakistan [35].

\section{Methods}

Bacterial samples and drug susceptibility tests

From 2011 to 2013, 93 clinical isolates of A. baumannii were obtained from respiratory tract samples taken from patients hospitalized in an intensive care unit (ICU) in Cho Ray Hospital in Ho Chi Minh City, Vietnam.

MICs of amikacin, arbekacin, ciprofloxacin, colistin, imipenem, meropenem, and tigecycline were determined using the microdilution method, as described [36].

\section{Whole genome sequences}

Genomic DNA from the 93 multidrug-resistant isolates were extracted using DNeasy Blood \& Tissue kits (QIAGEN, Tokyo, Japan) and sequenced by MiSeq (Illumina, San Diego, CA). MiSeq data, including total length, number of contig, N50, average contig length and \% GC content, were shown in Additional file 1: Table S1. To identify SNPs among these genomes, all reads of each isolate were aligned against the A. baumannii TYTH-1 sequence (Accession no. CP003856) using CLC genomics workbench, version 5.5 (CLC bio, Tokyo, Japan). SNP concatenated sequences were aligned by MAFFT (http://mafft.cbrc.jp/alignment/server/). A maximumlikelihood phylogenetic tree was constructed from the SNP alignment with PhyML 3.0 [37]. The probability of node branching was evaluated with 100 bootstrappings. Raw reads of all isolates were assembled into more than 500 bp contigs by CLC genomics workbench. Contigs around drug-resistant genes were annotated using the BLAST database (http://blast.ncbi.nlm.nih.gov/Blast.cgi?CMD=Web\&PAGE_TYPE=BlastHome). Multilocus sequence typing (MLST) based on contig data was deduced using CLC genomics workbench, and matched against the Institut Pasteur MLST (http://pubmlst.org/abaumannii/) databases. The result of STs according to PubMLST (http://pubmlst.org/abaumannii/) scheme was shown in Additional file 2: Table S2. Annotations using the RAST server (http://rast.nmpdr.org/) were performed to compare numbers of prophages and resistance factors. All raw read data of the 93 isolates have been deposited at GenBank as accession numbers DRX032164 to DRX032256.

\section{Ethical approval}

The study protocol was carefully reviewed and approved by the ethics committee of Cho Ray Hospital (approval number: 1644/QD-BVCR), the ethics committee of the National Center for Global Health and Medicine (No. 1268), and the Biosafety Committee of the National Center for Global Health and Medicine (approval number: 27-M-52), respectively. Individual informed consent was waived by the ethics committee listed above because this study used currently existing sample collected during the course of routine medical care and did not pose any additional risks to the patients.

\section{Results}

\section{Drug susceptibility tests}

The majority of the A. baumannii isolates tested were highly resistant to carbapenems, aminoglycosides, and ciprofloxacin, but sensitive to colistin and tigecycline (Table 1 ). MICs were $0.5->512 \mu \mathrm{g} / \mathrm{mL}\left(\mathrm{MIC}_{50}>512 \mu \mathrm{g} / \mathrm{mL}\right.$ and $\left.\mathrm{MIC}_{90}>512 \mu \mathrm{g} / \mathrm{mL}\right)$ to amikacin, $32->512 \mu \mathrm{g} / \mathrm{mL}$ $\left(\mathrm{MIC}_{50}>512 \mu \mathrm{g} / \mathrm{mL}\right.$ and $\mathrm{MIC}_{90}>512 \mu \mathrm{g} / \mathrm{mL}$ ) to ciprofloxacin, $0.125-16 \mu \mathrm{g} / \mathrm{mL}\left(\mathrm{MIC}_{50}=0.5 \mu \mathrm{g} / \mathrm{mL}\right.$ and $\mathrm{MIC}_{90}=$ $1 \mu \mathrm{g} / \mathrm{mL}$ ) to colistin, $8-128 \mu \mathrm{g} / \mathrm{mL}\left(\mathrm{MIC}_{50}=32 \mu \mathrm{g} / \mathrm{mL}\right.$ and $\mathrm{MIC}_{90}=64 \mu \mathrm{g} / \mathrm{mL}$ ) to imipenem, 4 to $128 \mu \mathrm{g} / \mathrm{mL}$ $\left(\mathrm{MIC}_{50}=32 \mu \mathrm{g} / \mathrm{mL}\right.$ and $\left.\mathrm{MIC}_{90}=64 \mu \mathrm{g} / \mathrm{mL}\right)$ to meropenem, and $<0.125-16 \mu \mathrm{g} / \mathrm{mL} \quad\left(\mathrm{MIC}_{50}=1 \mu \mathrm{g} / \mathrm{mL}\right.$ and $\mathrm{MIC}_{90}=8 \mu \mathrm{g} / \mathrm{mL}$ ) to tigecycline. The isolate NCGM321 was particularly resistant to carbapenems and aminoglycosides, with MICs of $>512 \mu \mathrm{g} / \mathrm{mL}$ to amikacin, $>512 \mu \mathrm{g} / \mathrm{mL}$ to arbekaein, $512 \mu \mathrm{g} / \mathrm{mL}$ to ciprofloxacin, $0.25 \mu \mathrm{g} / \mathrm{mL}$ to colistin, $128 \mu \mathrm{g} / \mathrm{mL}$ to imipenem, $64 \mu \mathrm{g} / \mathrm{mL}$ to meropenem, and $2 \mu \mathrm{g} / \mathrm{mL}$ to tigecycline.

\section{Molecular epidemiology and drug resistant genes}

Phylogenic analysis based on SNP concatenation showed that the 93 isolates belonged to seven clades, ST2 (28 isolates), ST16 (two isolates), ST23 (seven isolates), ST215 (seven isolates), ST570 (19 isolates), ST571 (28 isolates), and ST575 (11 isolates) (Fig. 1). The isolates in Clades ST2, ST570, and ST571 belonged to worldwide clonal lineage II

Table $1 \mathrm{MIC}_{50}$ and $\mathrm{MIC}_{90}$ values and antimicrobial resistance of the $93 \mathrm{~A}$. baumannii isolates

\begin{tabular}{llllll}
\hline Antimicrobial agents & Breakpoint for resistance $(\mathrm{mg} / \mathrm{L})$ & \% Resistant & Range $(\mathrm{mg} / \mathrm{L})$ & $\mathrm{MIC}_{50}(\mathrm{mg} / \mathrm{L})$ & $\mathrm{MIC}(\mathrm{mg} / \mathrm{L})$ \\
\hline Imipenem & $\geq 8$ & 100 & $8-128$ & 32 & 64 \\
Meropenem & $\geq 8$ & 99 & $4-128$ & 32 & 64 \\
Amikacin & $\geq 64$ & 87 & $0.5->512$ & $>512$ & $>512$ \\
Ciprofloxacin & $\geq 4$ & 100 & $32->512$ & $>512$ & $>512$ \\
Colistin & $\geq 4$ & 5 & $0.125-16$ & 0.5 & 1 \\
Tigecycline & - & - & $\leq 0.125-16$ & 1 & 8 \\
\hline
\end{tabular}




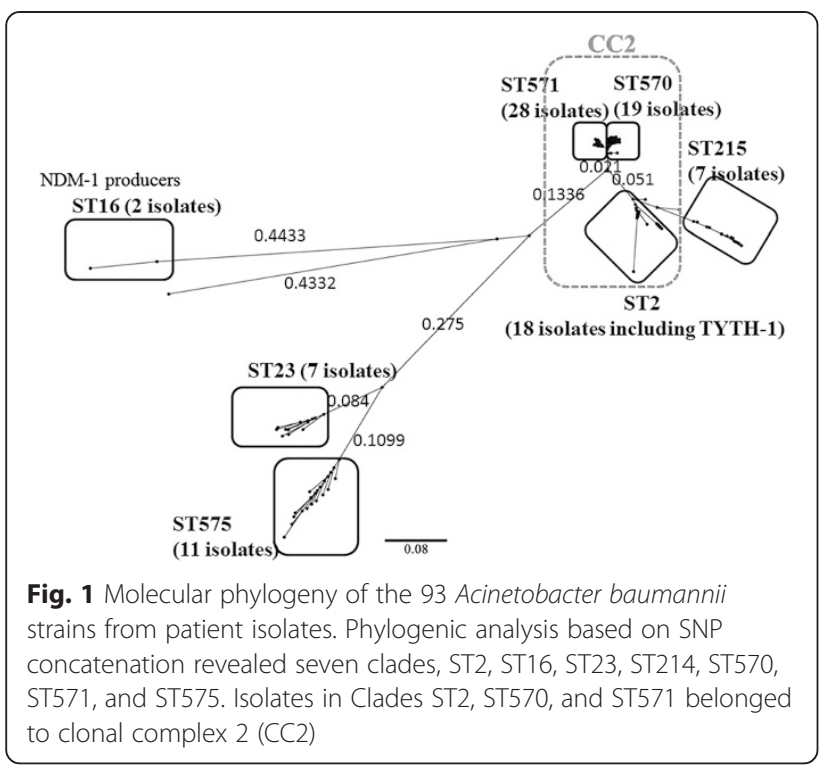

(CC2, European Clone II) [38]. All isolates tested contained intrinsic $b l a_{\mathrm{ADC}}$. No novel $b l a_{\mathrm{ADC}}$ gene was detected. None of the intrinsic $b l a_{\mathrm{ADC}}$ genes contained ISAbal, which is responsible for the overexpression of these genes [39]. The intrinsic $b l a_{\mathrm{ADC}}$ genes encoded clade-specific $b l a_{\mathrm{OXA}-51 \text {-like }}$ variants, with the 71 isolates belonging to Clades ST2, ST215, ST570, and ST571 having bla ${ }_{\text {OXA-66, }}$ the 11 isolates belonging to ST575 having bla $a_{\mathrm{OXA}-144}$, the seven isolates belonging to ST23 having $b l a_{\mathrm{OXA}-68}$, and the two isolates belonging to ST16 having $b a_{\text {OXA-51 }}$ (Table 2). The 2 isolates belonging to ST16 also contained the bla $a_{\mathrm{NDM}-1}$, $b l a_{\text {OXA- } 58}$, and $b l a_{\mathrm{VEB}-1}$ genes. Of the all 93 isolates tested, 71 had $b l a_{\mathrm{TEM}-1}, 56$ had $b l a_{\mathrm{OXA}-23}$, and three had $b l a_{\mathrm{VEBS}}$.

Among the 93 isolates, 77 had armA, 77 had aadA1, 34 had $a a c\left(6^{\prime}\right)-I b-c r, 28$ had $a p h\left(3^{\prime}\right)-I a, 18$ had aac(3)-Ia, 12 had $\operatorname{aph}\left(3^{\prime}\right)-$ Via, 10 had $a p h\left(3^{\prime}\right)-V i b$, seven had aac(3)-Iid, five had $a p h A 6$, and one had $a a c(3)-I b$. No plasmid was detected in any of the 93 isolates, indicating that all drug resistance genes were located on chromosomes.

\section{Genomic environments surrounding $\operatorname{arm} A, b / a_{\text {OXA-23 }}$}

bla $a_{\mathrm{NDM}-1}, b / a_{\mathrm{OXA}-51-l i k e}$ and $b / a_{\mathrm{OXA}-58}$

The genetic environment surrounding armA in NCGM346 belonging to Clade ST571 (Accession no. LC030435) is shown in Fig. 2a. This genetic environment, from nt 1 to nt 17,473 , was more than $99.99 \%$ homologous to the analogous region of $A$. baumannii strains MDR-TJ isolated in China [40] and NCGM253 isolated in Japan [41]. The sequence surrounding armA from nt 5838 to nt 9879 was identical to the transposon $\operatorname{Tn} 1548$ (Accession no. EU014811) detected in an A. baumannii isolate from North America [42] and included the ISCR1 insertion sequence. Putative transposase genes were located both upstream $(t n p U)$ and downstream $(t n p D)$ of $\operatorname{armA}$ (Fig. 2a). Four additional isolates, NCGM165, NCGM169, NCGM175, and NCGM194, belonging to Clades ST570, ST215, ST23, and ST2, respectively, had the same genetic organization surrounding armA as the NCGM346 isolate. None of these five isolates contained plasmids, indicating that $\operatorname{arm} A$ is chromosomally encoded in each.

The genetic environment surrounding $b l a_{\mathrm{NDM}-1}$ in NCGM321 belonging to Clade ST16 (Accession no. LC032101) is shown in Fig. 2b. The bla $a_{\mathrm{NDM}-1}$ gene was located between two copies of ISAba125 and was carried by the $\operatorname{Tn} 125$ composite transposon. The genetic environment surrounding bla $a_{\mathrm{NDM}-1}$ was $100 \%$ homologous to those of $A$. baumannii strain IOMTU433 isolated in Nepal (accession no. AP014649), A. baumannii ZW85-1 plasmid pAbNDM-1 isolated in China (accession no. JN377410), Acinetobacter lwoffii WJ10621

Table 2 MLST and drug resistance genes in A. baumannii isolates

\begin{tabular}{|c|c|c|c|}
\hline$\overline{M L S T}$ & No. of isolates ${ }^{a}$ & Carbapenemase and ESBL encoding genes & Aminoglycoside-resistance genes \\
\hline ST2 (CC2) & 17 & $\begin{array}{l}\text { bla } a_{\mathrm{OXA}-66}, \text { bla } \\
\text { bla }_{\mathrm{TEM}-1}(16 / 17)\end{array}$ & $\begin{array}{l}\operatorname{armA}, \operatorname{aac}\left(6^{\prime}\right)-\operatorname{lb}-\operatorname{cr}(13 / 17), \operatorname{aac}(3)-\operatorname{la}(1 / 17), \operatorname{aadA1}(14 / 17) \\
\operatorname{aph}\left(3^{\prime}\right)-\operatorname{la}(14 / 17)\end{array}$ \\
\hline ST16 & 2 & $\begin{array}{l}\text { bla }_{\mathrm{NDM}-1}, b a_{\mathrm{OXA}-51}, b l a_{\mathrm{OXA}-58}, b l a_{\mathrm{VEB}-1} \\
\text { bla }_{\mathrm{TEM}-1}(1 / 2)\end{array}$ & $\operatorname{armA}(1 / 2), \operatorname{aac}(3)-l i d, \operatorname{aadA1}, \operatorname{aadB}, \operatorname{aph}\left(3^{\prime}\right)$-Via \\
\hline ST23 & 7 & bla $a_{\mathrm{OXA}-23}(2 / 7), b l a_{\mathrm{OXA}-68}, b / a_{\mathrm{PER}-1}, b / a_{\mathrm{TEM}-1}(1 / 23)$ & 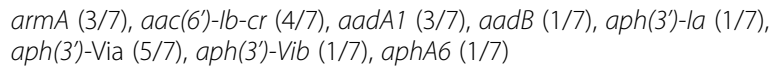 \\
\hline ST215 & 7 & $b l a_{\mathrm{OXA}-23}(4 / 7), b l a_{\mathrm{OXA}-66}, b / a_{\mathrm{TEM}-1}$ & $\begin{array}{l}\operatorname{armA}(6 / 7), \operatorname{aac}\left(6^{\prime}\right)-1 b(1 / 7), \operatorname{aac}\left(6^{\prime}\right)-1 b-c r(5 / 7), \operatorname{aac}(3)-l a(4 / 7), \operatorname{aadA}, \\
\operatorname{aph}\left(3^{\prime}\right)-1 a(5 / 7)\end{array}$ \\
\hline ST570 (CC2) & 19 & $b l a_{\mathrm{OXA}-23}(9 / 19), b l a_{\mathrm{OXA}-66}, b / a_{\mathrm{TEM}-1}(18 / 19)$ & $\begin{array}{l}\operatorname{armA}, \operatorname{aac}\left(6^{\prime}\right)-1 b(7 / 19), \operatorname{aac}\left(6^{\prime}\right)-1 b-c r(11 / 19), \operatorname{aac}(3)-l a, a a d A 1 \\
\operatorname{aph}\left(3^{\prime}\right)-1 a(7 / 19)\end{array}$ \\
\hline ST571 (CC2) & 28 & $b l a_{\mathrm{OXA}-23}(22 / 28), b l a_{\mathrm{OXA}-66}, b l a_{\mathrm{PER}-1}(5 / 28), b / a_{\mathrm{TEM}-1}$ & $\begin{array}{l}\operatorname{armA}, \operatorname{aac}(3) \text {-lid (4/28), aadA1, aadB (2/28), aph(3')-Via (1/28), } \\
\operatorname{aph}\left(3^{\prime}\right)-\operatorname{Vib}(4 / 28)\end{array}$ \\
\hline ST575 & 11 & bla $a_{\mathrm{OXA}-23}(9 / 11), b / a_{\mathrm{OXA}-144}, b / a_{\mathrm{PER}-1}, b / a_{\mathrm{TEM}-1}$ & $\operatorname{aadB}(5 / 11), \operatorname{aph}\left(3^{\prime}\right)-\operatorname{Via}(3 / 11), \operatorname{aph}\left(3^{\prime}\right)-\operatorname{Vib}(4 / 11)$, aphA6 (4/11) \\
\hline ST577 & 1 & bla $a_{\mathrm{OXA}-23}, b l a_{\mathrm{OXA}-66}, b / a_{\mathrm{TEM}-1}$ & $\operatorname{arm} A, \operatorname{aac}\left(6^{\prime}\right)-1 b, \operatorname{aac}(3)-l a, a a d A 1$ \\
\hline ST578 & 1 & $b / a_{\mathrm{OXA}-51}, b a_{\mathrm{OXA}-58}, b a_{\mathrm{VEB}-7}$ & $\operatorname{aac}(3)-16, \operatorname{aadA1}, \operatorname{aph}\left(3^{\prime}\right)-\mathrm{Via}$ \\
\hline
\end{tabular}

${ }^{a}$ Total number of isolates belonging to the same sequence type 


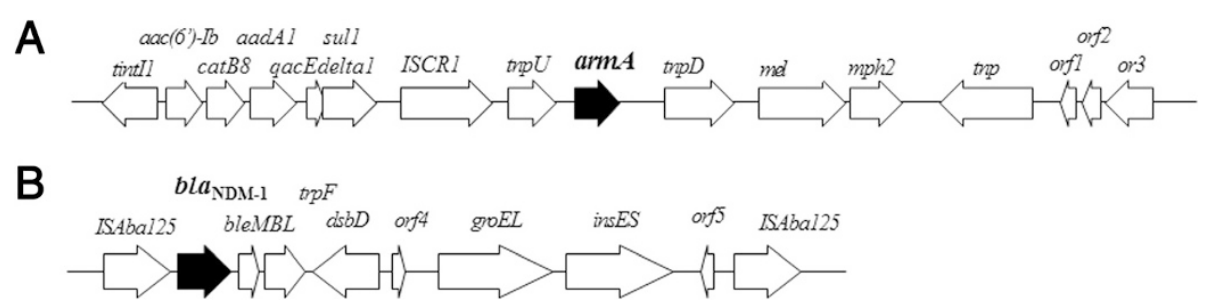

Fig. 2 Genetic environments of armA and bla $a_{N D M-1}$ in A. baumannii NCGM346 (a) and NCGM321 (b). orf1, gene encoding a hypothetical protein; orf2, gene encoding a DNA-binding protein; orf3, gene encoding a DNA replication protein; orf4 and orf5, genes encoding hypothetical proteins

plasmid pNDM-BJ01 isolated in China (accession no. JQ001701), and A. baumannii 161/07 isolated in Germany (accession no. HQ857107). The genetic environment surrounding bla $a_{\mathrm{NDM}-1}$ in NCGM328, the second isolate belonging to Clade ST16, was identical to the genetic environment surrounding bla $a_{\mathrm{NDM}-1}$ in NCGM321.

The genetic environment surrounding $b a_{\mathrm{OXA}-23}$ in NCGM346 belonging to Clade ST571 was ISAba1bla $a_{\text {OXA-23-yeeA (yeeA: ATPase encoding gene) and }}$ was more than $99 \%$ identical with chromosome sequences of A. baumannii strains IOMTU433 (accession no. AP014649) and NCGM237 [41]. The genetic organization surrounding $b l a_{\mathrm{OXA}-23}$ in four additional isolates, NCGM165, NCGM169, NCGM175, and NCGM194, belonging to Clades ST570, ST215, ST23, and ST2, respectively, was identical to that surrounding $b l a_{\mathrm{OXA}-23}$ in NCGM346.

The genetic environment surrounding $b l a_{\text {OXA-51-like }}$ in NCGM346 belonging to Clade ST571 was $f \times s A-b l a_{\text {OXA- }}$ 66-orf6-orf7-ruvC-orf8-gueG-bioB, where orf6 encodes the enzyme phosphinothricin $\mathrm{N}$-acetyltransferase, orf7 encodes an XRE family transcriptional regulator, and orf8 encodes a hypothetical protein. The same genetic organization surrounding bla $a_{\text {OXA-51-like }}$ was observed in four additional isolates, NCGM165, NCGM169, NCGM175, and NCGM194, belonging to Clades ST570, ST215, ST23, and ST2, respectively.

The genetic environment surrounding $b a_{\text {OXA-58 }}$ in NCGM328 belonging to Clade ST16 was ISAba3-

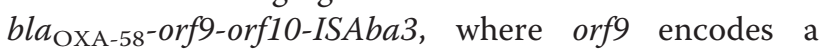
transposon-related protein and orf 10 encodes a hypothetical protein. The structure was the same as a part of Acinetobacter spp. M131 plasmid pM131-2 (accession no. JX101647).

\section{Structures of the genomic resistance islands of CC2 isolates}

The resistance island (RI) of the isolate NCGM196 belonging to Clade ST2 contained two Tn6021-like copies and one Tn5393-like copy. The resistance genes in the RI included sul1, which encodes sulfonamide resistance protein, and tet $B$ and tet $R$, which regulate tetracycline resistance, as well as the streptomycin resistance genes strA and strB. The RI structure of the other ST2 isolate (NCGM194) was identical to that of $A$. baumannii MDT-TJ [40] and TYTH-1 [43]. RIs of the isolates belonging to Clades ST570 (NCGM165) and ST571 (NCGM346) were identical to those of AbaR4 [44], a compound transposon containing a Tn6022 backbone.

\section{Prophages and resistance factors}

The A. baumannii isolates had several transposable elements, phages/prophages and resistance factors. The isolates belonging to international clone 2, including NCGM165 (ST570), NCGM194 (ST2) and NCGM346 (ST571), had fewer phages/prophages than the isolates belonging to other clones, including NCGM169 (ST215), NCGM175 (ST23) and NCGM328 (ST16). The isolates NCGM165, NCGM194, NCGM346, NCGM169, NCGM1 75 , and NCGM328 contained 10, 18, 10, 8, 7, and 6 transposable elements, respectively; 54, $6080,57,57$ and 57 resistance factors, respectively; and $11,8,8,27,49$ and 32 phages/prophages, respectively.

\section{Discussion}

To our knowledge, this is the first report of $A$. baumannii isolates co-producing NDM-1 and ArmA emerging in a medical setting in Vietnam. Enterobacteriaceae producing only NDM-1 had been reported in Vietnam $[18,45,46]$, including NDM-1-producing $K$. pneumoniae isolated from environmental samples [45] and NDM-1-producing Enterobacteriaceae isolated from samples in a Vietnamese surgical hospital [47]. There have been no reports of $A$. baumannii co-producing NDM-1 and ArmA and belonging to international clone 2, although NDM-1 producers belonging to international clone2 were reported in East Africa in 2013 [48]. It is important to continue the surveillance of NDM-1-producing pathogens, including $A$. baumannii, in medical settings in Vietnam.

The high prevalence of Gram-negative bacteria producing ArmA in Vietnam may result from the inadequate use of aminoglycosides in that country. An analysis of patients hospitalized in Vietnam showed that $67.4 \%$ received antibiotics, with $18.9 \%$ receiving aminoglycosides, although 
$30.8 \%$ of the prescribed antibiotics were considered inappropriate [49]. This latter rate was higher than the rates of inappropriately prescribed antibiotics in Malaysia (4.0 \%) [50], Turkey (14.0 \%) [51], Hong Kong (20.0\%) [52] and European countries (17.8-32.0 \%) [53, 54].

A similar genetic environment surrounding bla $a_{\mathrm{NDM}-1}$ has been reported in A. baumannii stains isolated in China [55], Colombia (accession no. CP010399), France [22], Germany [56] and the United States (accession no. CP010370); in A. lwoffii isolated in China [57]; in E. coli isolated in Colombia (accession no. CP010373); in $K$. pneumoniae isolated in Colombia (CP010391) and the United States [58]; and in Providencia rettgeri isolated in Canada [59]. A similar environment surrounding $\operatorname{armA}$ was reported in A. baumannii strains isolated in China [40], Japan [41], and Nepal (accession no. AP014649). The genetic organization of $b l a_{\mathrm{NDM}-1}$ has spread worldwide, whereas that of $\operatorname{arm} A$ has spread in Asian countries.

A. baumannii isolates belonging to international clone 2 must have been disseminated throughout medical settings in Vietnam, since $69.9 \%$ of all isolates tested belonged to this clone (ST2, ST570, and ST571). Epidemiological studies of $A$. baumannii isolates obtained from a hospital in Hanoi are currently ongoing to clarify whether $A$. baumannii isolates belonging to international clone 2 are disseminating throughout Vietnam. The isolates belonging to Clades ST16, ST23, and ST215 were not identified as belonging to any previously described international clones [38]. To date, one A. baumannii isolate belonging to Clade ST16 was isolated in 2001 in the Netherlands, 3 isolates belonging to ST23 were isolated in the Netherlands (in 1964) and Sweden (in 2006 and 2007), and 6 isolates belonging to Clade ST215 were isolated in 2008 in China. Clones ST570, ST571, and ST575 were novel STs. Of the isolates belonging to CC2, those in Clades ST570 and ST571 may have evolved in a unique manner in Vietnam because the structures of resistant islands in ST570 and ST571 isolates were different from those in ST2 isolates.

\section{Conclusions}

This study showed that $16 \mathrm{~S}$ rRNA methylase ArmAproducing A. baumannii isolates belonging to clonal complex 2 have spread, and that NDM-1-and ArmA-coproducers not belonging to clonal complex 2 are emerging, in medical settings in Vietnam.

\section{Additional files}

Additional file 1: Table S1. Assembly summary report of $93 \mathrm{~A}$. baumannii isolates using CLC Genomics Workbench version 5.5. (XLSX $15 \mathrm{~kb})$

Additional file 2: Table S2. MLST analysis on PubMLST scheme in $93 \mathrm{~A}$. baumannii isolates. (XLSX $14 \mathrm{~kb}$ )

\section{Abbreviations}

MBLs: Metallo- $\beta$-lactamases; MLST: Multilocus sequence typing; IP-MLST: Institut Pasteur MLST.

\section{Competing interests}

The authors declare that they have no competing interest.

\section{Authors' contributions}

TT: Performed whole genome sequencing, analyzed data and drafted the manuscript. TMA: Performed whole genome sequencing. KS: Performed drug-susceptibility tests. TTN: Performed clinical bacterial analyses. LTAT and NTS: Designed protocols and supervised this study at CRH. NO and TK: Designed protocols and supervised this study. All authors read and approved the final manuscript.

\section{Acknowledgements}

This study was supported by Japan Initiative for Global Research Network on Infectious Diseases (J-GRID), and a grant of the Research Program on Emerging and Re-emerging Infectious Diseases from Japan Agency for Medical Research and Development, and a grant (26-A-103) from International Health Cooperation Research.

\section{Author details}

'Department of Infectious Diseases, Research Institute, National Center for Global Health and Medicine, Shinjuku, Tokyo, Japan. ${ }^{2}$ Pathogenic Microbe Laboratory, Research Institute, National Center for Global Health and Medicine, Shinjuku, Tokyo, Japan. ${ }^{3}$ Cho Ray Hospital, Ho Chi Minh, Vietnam. ${ }^{4}$ Disease Control and Prevention Center, Division of Infectious Diseases, National Center for Global Health and Medicine, 1-21-1 Toyama, Shinjuku, Tokyo 162-8655, Japan.

Received: 8 April 2015 Accepted: 1 October 2015

Published online: 15 October 2015

\section{References}

1. Bush K. New beta-lactamases in gram-negative bacteria: diversity and impact on the selection of antimicrobial therapy. Clin Infect Dis. 2001;32(7):1085-9.

2. Walsh TR, Toleman MA, Poirel L, Nordmann P. Metallo-beta-lactamases: the quiet before the storm? Clin Microbiol Rev. 2005;18(2):306-25.

3. Bush K, Jacoby GA. Updated functional classification of beta-lactamases. Antimicrob Agents Chemother. 2010;54(3):969-76.

4. Cornaglia G, Giamarellou H, Rossolini GM. Metallo-beta-lactamases: a last frontier for beta-lactams? Lancet Infect Dis. 2011;11(5):381-93.

5. Yong D, Toleman MA, Bell J, Ritchie B, Pratt R, Ryley H, et al. Genetic and biochemical characterization of an acquired subgroup B3 metallo-betalactamase gene, bla $a_{\mathrm{AlM}-1}$, and its unique genetic context in Pseudomonas aeruginosa from Australia. Antimicrob Agents Chemother. 2012;56(12):6154-9.

6. Rogalski TM, Gilbert MM, Devenport D, Norman KR, Moerman DG. DIM-1, a novel immunoglobulin superfamily protein in Caenorhabditis elegans, is necessary for maintaining bodywall muscle integrity. Genetics. 2003;163(3):905-15.

7. Pollini S, Maradei S, Pecile P, Olivo G, Luzzaro F, Docquier JD, et al. FIM-1, a new acquired metallo-beta-lactamase from a Pseudomonas aeruginosa clinical isolate from Italy. Antimicrob Agents Chemother. 2013;57(1):410-6.

8. Castanheira M, Toleman MA, Jones RN, Schmidt FJ, Walsh TR. Molecular characterization of a beta-lactamase gene, bla $a_{\mathrm{GIM}-1}$, encoding a new subclass of metallo-beta-lactamase. Antimicrob Agents Chemother. 2004;48(12):4654-61.

9. Osano E, Arakawa Y, Wacharotayankun R, Ohta M, Horii T, Ito H, et al. Molecular characterization of an enterobacterial metallo beta-lactamase found in a clinical isolate of Serratia marcescens that shows imipenem resistance. Antimicrob Agents Chemother. 1994;38(1):71-8.

10. Sekiguchi J, Morita K, Kitao T, Watanabe N, Okazaki M, Miyoshi-Akiyama T, et al. KHM-1, a novel plasmid-mediated metallo-beta-lactamase from a Citrobacter freundii clinical isolate. Antimicrob Agents Chemother. 2008;52(11):4194-7.

11. Yong D, Toleman MA, Giske CG, Cho HS, Sundman K, Lee K, et al. Characterization of a new metallo-beta-lactamase gene, bla $a_{\mathrm{NDM}-1}$, and a novel erythromycin esterase gene carried on a unique genetic structure in 
Klebsiella pneumoniae sequence type 14 from India. Antimicrob Agents Chemother. 2009;53(12):5046-54.

12. Wachino J, Yoshida H, Yamane K, Suzuki S, Matsui M, Yamagishi T, et al. SMB-1, a novel subclass B3 metallo-beta-lactamase, associated with ISCR1 and a class 1 integron, from a carbapenem-resistant Serratia marcescens clinical isolate. Antimicrob Agents Chemother. 2011:55(11):5143-9.

13. Lee K, Yum JH, Yong D, Lee HM, Kim HD, Docquier JD, et al. Novel acquired metallo-beta-lactamase gene, bla $a_{\mathrm{SIM}-1}$, in a class 1 integron from Acinetobacter baumannii clinical isolates from Korea. Antimicrob Agents Chemother. 2005;49(11):4485-91.

14. Zavascki AP, Gaspareto PB, Martins AF, Goncalves AL, Barth AL. Outbreak of carbapenem-resistant Pseudomonas aeruginosa producing SPM-1 metallo-betalactamase in a teaching hospital in southern Brazil. J Antimicrob Chemother. 2005:56(6):1148-51.

15. El Salabi A, Borra PS, Toleman MA, Samuelsen O, Walsh TR. Genetic and biochemical characterization of a novel metallo-beta-lactamase, TMB-1, from an Achromobacter xylosoxidans strain isolated in Tripoli, Libya. Antimicrob Agents Chemother. 2012;56(5):2241-5.

16. Lauretti L, Riccio ML, Mazzariol A, Cornaglia G, Amicosante G, Fontana R, et al. Cloning and characterization of bla $\mathrm{yIM}_{\mathrm{m}}$, a new integron-borne metallo-beta-lactamase gene from a Pseudomonas aeruginosa clinical isolate. Antimicrob Agents Chemother. 1999;43(7):1584-90.

17. Jacoby GA, Munoz-Price LS. The new beta-lactamases. N Engl J Med. 2005;352(4):380-91.

18. Berrazeg M, Diene S, Medjahed L, Parola P, Drissi M, Raoult D, et al. New Delhi Metallo-beta-lactamase around the world: an eReview using Google Maps. Euro Surveill. 2014;19(20):20809.

19. Pillai DR, McGeer A, Low DE. New Delhi metallo-beta-lactamase-1 in Enterobacteriaceae: emerging resistance. CMAJ. 2011;183(1):59-64.

20. Kaase M, Nordmann P, Wichelhaus TA, Gatermann SG, Bonnin RA, Poirel L. NDM-2 carbapenemase in Acinetobacter baumannii from Egypt. J Antimicrob Chemother. 2011;66(6):1260-2.

21. Espinal P, Fugazza G, Lopez Y, Kasma M, Lerman Y, Malhotra-Kumar S, et al Dissemination of an NDM-2-producing Acinetobacter baumannii clone in an Israeli rehabilitation center. Antimicrob Agents Chemother. 2011;55(11):5396-8.

22. Poirel L, Bonnin RA, Boulanger A, Schrenzel J, Kaase M, Nordmann P.

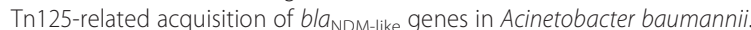
Antimicrob Agents Chemother. 2012;56(2):1087-9.

23. Ghazawi A, Sonnevend A, Bonnin RA, Poirel L, Nordmann P, Hashmey R, et al. NDM-2 carbapenemase-producing Acinetobacter baumannii in the United Arab Emirates. Clin Microbiol Infect. 2012:18(2):E34-6.

24. Rogers BA, Sidjabat HE, Silvey A, Anderson TL, Perera S, Li J, et al. Treatment options for New Delhi metallo-beta-lactamase-harboring Enterobacteriaceae. Microb Drug Resist. 2013;19(2):100-3.

25. Nordmann P, Boulanger AE, Poirel L. NDM-4 metallo-beta-lactamase with increased carbapenemase activity from Escherichia coli. Antimicrob Agents Chemother. 2012;56(4):2184-6.

26. Hornsey M, Phee L, Wareham DW. A novel variant, NDM-5, of the New Delhi metallo-beta-lactamase in a multidrug-resistant Escherichia coli ST648 isolate recovered from a patient in the United Kingdom. Antimicrob Agents Chemother. 2011;55(12):5952-4.

27. Williamson DA, Sidjabat HE, Freeman JT, Roberts SA, Silvey A, Woodhouse $\mathrm{R}$, et al. Identification and molecular characterisation of New Delhi metallo-beta-lactamase-1 (NDM-1)- and NDM-6-producing Enterobacteriaceae from New Zealand hospitals. Int J Antimicrob Agents. 2012;39(6):529-33

28. Cuzon G, Bonnin RA, Nordmann P. First identification of novel NDM carbapenemase, NDM-7, in Escherichia coli in France. PLoS One. 2013;8(4):e61322.

29. Gottig S, Hamprecht AG, Christ S, Kempf VA, Wichelhaus TA. Detection of NDM-7 in Germany, a new variant of the New Delhi metallo-beta-lactamase with increased carbapenemase activity. J Antimicrob Chemother. 2013;68(8):1737-40.

30. Tada T, Miyoshi-Akiyama T, Dahal RK, Sah MK, Ohara H, Kirikae T, et al. NDM-8 Metallo-beta-Lactamase in a Multidrug-Resistant Escherichia coli Strain Isolated in Nepal. Antimicrob Agents Chemother. 2013.

31. Jana S, Deb JK. Molecular understanding of aminoglycoside action and resistance. Appl Microbiol Biotechnol. 2006;70(2):140-50.

32. Doi Y, Arakawa Y. 165 ribosomal RNA methylation: emerging resistance mechanism against aminoglycosides. Clin Infect Dis. 2007;45(1):88-94.
33. Galimand M, Courvalin P, Lambert T. Plasmid-mediated high-level resistance to aminoglycosides in Enterobacteriaceae due to 165 rRNA methylation. Antimicrob Agents Chemother. 2003;47(8):2565-71.

34. Yamane K, Wachino J, Suzuki S, Shibata N, Kato H, Shibayama K, et al. $16 \mathrm{~S}$ rRNA methylase-producing, gram-negative pathogens, Japan. Emerg Infect Dis. 2007;13(4):642-6.

35. Wachino J, Arakawa Y. Exogenously acquired 16S rRNA methyltransferases found in aminoglycoside-resistant pathogenic Gram-negative bacteria: An update. Drug Resist Updat. 2012;15(3):133-48.

36. Clinical and Laboratory Standards Institute. Performance standards for antimicrobial susceptibility testing; 25th informational supplement, CLSI M100-S25. Clinical and Laboratory Standards Institute. 7th ed. Wayne: Clinical and Laboratory Standards Institute; 2015.

37. Guindon S, Dufayard JF, Lefort V, Anisimova M, Hordijk W, Gascuel O. New algorithms and methods to estimate maximum-likelihood phylogenies: assessing the performance of PhyML 3.0. Syst Biol. 2010;59(3):307-21.

38. Zarrilli R, Pournaras S, Giannouli M, Tsakris A. Global evolution of multidrugresistant Acinetobacter baumannii clonal lineages. Int J Antimicrob Agents 2013:41(1):11-9.

39. Jacoby GA. AmpC beta-lactamases. Clin Microbiol Rev. 2009;22(1):161-82 Table of Contents.

40. Huang H, Yang ZL, Wu XM, Wang Y, Liu YJ, Luo H, et al. Complete genome sequence of Acinetobacter baumannii MDR-TJ and insights into its mechanism of antibiotic resistance. J Antimicrob Chemother. 2012;67(12):2825-32.

41. Tada T, Miyoshi-Akiyama T, Shimada K, Shimojima M, Kirikae T. Dissemination of 165 rRNA Methylase ArmA-Producing Acinetobacter baumannii and Emergence of OXA-72 Carbapenemase Coproducers in Japan. Antimicrob Agents Chemother. 2014;58(5):2916-20.

42. Doi $Y$, Adams JM, Yamane K, Paterson DL. Identification of 165 rRNA methylase-producing Acinetobacter baumannii clinical strains in North America. Antimicrob Agents Chemother. 2007;51(11):4209-10.

43. Liu CC, Tang CY, Kuo HY, Lu CW, Chang KC, Liou ML. The origin of Acinetobacter baumannii TYTH-1: a comparative genomics study. Int J Antimicrob Agents. 2013;41(4):318-24.

44. Hamidian M, Hall RM. AbaR4 replaces AbaR3 in a carbapenem-resistant Acinetobacter baumannii isolate belonging to global clone 1 from an Australian hospital. J Antimicrob Chemother. 2011;66(11):2484-91.

45. Isozumi R, Yoshimatsu K, Yamashiro T, Hasebe F, Nguyen BM, Ngo TC, et al bla $a_{\text {DM-1-1 }}$-positive Klebsiella pneumoniae from environment. Vietnam Emerg Infect Dis. 2012;18(8):1383-5.

46. Nhu NT, Lan NP, Campbell Jl, Parry CM, Thompson C, Tuyen HT, et al. Emergence of carbapenem-resistant Acinetobacter baumannii as the major cause of ventilator-associated pneumonia in intensive care unit patients at an infectious disease hospital in southern Vietnam. J Med Microbiol. 2014;63(Pt 10):1386-94

47. Tran HH, Ehsani S, Shibayama K, Matsui M, Suzuki S, Nguyen MB, et al. Common isolation of New Delhi metallo-beta-lactamase 1-producing Enterobacteriaceae in a large surgical hospital in Vietnam. Eur J Clin Microbiol Infect Dis. 2015.

48. Revathi G, Siu LK, Lu PL, Huang LY. First report of NDM-1-producing Acinetobacter baumannii in East Africa. Int J Infect Dis. 2013;17(12):e1255-8

49. Thu TA, Rahman M, Coffin S, Harun-Or-Rashid M, Sakamoto J, Hung NV. Antibiotic use in Vietnamese hospitals: A multicenter point-prevalence study. Am J Infect Control. 2012.

50. Hughes AJ, Ariffin N, Huat TL, Abdul Molok H, Hashim S, Sarijo J, et al. Prevalence of nosocomial infection and antibiotic use at a university medical center in Malaysia. Infect Control Hosp Epidemiol. 2005;26(1):100-4.

51. Ceyhan M, Yildirim I, Ecevit C, Aydogan A, Ornek A, Salman N, et al. Inappropriate antimicrobial use in Turkish pediatric hospitals: a multicenter point prevalence survey. Int J Infect Dis. 2010;14(1):e55-61.

52. Lee MK, Chiu CS, Chow VC, Lam RK, Lai RW. Prevalence of hospital infection and antibiotic use at a university medical center in Hong Kong. J Hosp Infect. 2007;65(4):341-7.

53. Hulscher ME, Grol RP, van der Meer JW. Antibiotic prescribing in hospitals: a social and behavioural scientific approach. Lancet Infect Dis. 2010;10(3):167-75.

54. Kritsotakis El, Dimitriadis I, Roumbelaki M, Vounou E, Kontou M, Papakyriakou P, et al. Case-mix adjustment approach to benchmarking prevalence rates of nosocomial infection in hospitals in Cyprus and Greece. Infect Control Hosp Epidemiol. 2008;29(8):685-92. 
55. Wang X, Zhang Z, Hao Q, Wu J, Xiao J, Jing H. Complete Genome Sequence of Acinetobacter baumannii ZW85-1. Genome Announc. 2014 doi:10.1128/genomeA.01083-13.

56. Pfeifer Y, Wilharm G, Zander E, Wichelhaus TA, Gottig S, Hunfeld KP, et al. Molecular characterization of bla $\mathrm{NDM}_{\mathrm{N}-1}$ in an Acinetobacter baumannii strain isolated in Germany in 2007. J Antimicrob Chemother. 2011;66(9):1998-2001.

57. Christianson SJ, Brand CL, Wilkinson GS. Reduced polymorphism associated with $X$ chromosome meiotic drive in the stalk-eyed fly Teleopsis dalmanni. PLoS One. 2011;6(11), e27254.

58. Doi Y, Hazen TH, Boitano M, Tsai YC, Clark TA, Korlach J, et al. Whole-genome assembly of Klebsiella pneumoniae coproducing NDM-1 and OXA-232 carbapenemases using single-molecule, real-time sequencing. Antimicrob Agents Chemother. 2014;58(10):5947-53.

59. Mataseje LF, Boyd DA, Lefebvre B, Bryce E, Embree J, Gravel D, et al. Complete sequences of a novel bla $a_{\text {NDM-1 }}$-harbouring plasmid from Providencia rettgeri and an Fll-type plasmid from Klebsiella pneumoniae identified in Canada. J Antimicrob Chemother. 2014;69(3):637-42.

\section{Submit your next manuscript to BioMed Central and take full advantage of:}

- Convenient online submission

- Thorough peer review

- No space constraints or color figure charges

- Immediate publication on acceptance

- Inclusion in PubMed, CAS, Scopus and Google Scholar

- Research which is freely available for redistribution 